\title{
EDUCAÇÃO JURÍDICA COMO FORMAÇÃO PARA A PROMOÇÃO DOS DIREITOS HUMANOS
}

\section{LEGAL EDUCATION FOR THE PROMOTION OF HUMAN RIGHTS}

Pedro Pulzatto Peruzzo ${ }^{1}$

Guilherme Perez Cabral²

Thiago Silva Freitas Oliveira ${ }^{3}$

\begin{abstract}
RESUMO: O objetivo do presente artigo é refletir sobre o tema da educaçăo jurídica no Brasil, analisando possibilidades, avanços e retrocessos para a sua compreensáo como formaçáo para a promoçáo dos direitos humanos. Para tanto, traremos ao campo jurídico reflexóes que, apesar de bastante desenvolvidas no âmbito geral das ciências humanas e sociais aplicadas e da filosofia, ainda năo foram devidamente assimiladas no universo jurídico. Partiremos da discussāo sobre o significado geral da educaçáo em direitos humanos destacando a ideia de autonomia que náo perde de vista a convivência e a inclusăo do outro. Analisaremos o contexto atual do ensino jurídico no Brasil destacando vícios ideológicos presentes na transmissăo "bancária" dos conhecimentos necessários para a atuaçăo no Sistema de Justiça e propondo caminhos para sua efetivaçấo como formaçâo para a promoçăo dos direitos humanos.
\end{abstract}

PALAVRA-CHAVE: Ensino jurídico; Direitos humanos; Democracia.

ABSTRACT: The purpose of this article is to reflect about legal education in Brazil, analyzing possibilities, advances and setbacks, understanding it as training for the promotion of human rights. To this end, we will bring to the legal field reflections that, although well developed in the general scope of applied human and social sciences and philosophy, have not yet been adequately assimilated into the legal universe. We will start from the discussion about the general meaning of human rights education highlighting the idea of autonomy that does not lose sight of the coexistence and the inclusion of the other. We will analyze the current context of legal education in Brazil highlighting ideological vices present in the "banking" transmission of the knowledge necessary for acting in the Justice System and proposing ways for its effectiveness as training for the promotion of human rights.

KEYWORD: Legal education; Human rights; Democracy.

1 Professor pesquisador da Faculdade de Direito da PUC-Campinas. Mestre e doutor em Direito pela Universidade de Sâo Paulo. peruzzopp@hotmail.com

2 Professor da Faculdade de Direito da PUC-Campinas. Mestre em Direito pela Universidade Metodista de Piracicaba (UNIMEP) e Doutor em Direito pela Universidade de Sáo Paulo (USP). gpcabral@gmail.com

3 Professor de filosofia do Centro de Ciências Humanas e Sociais Aplicadas da PUC-Campinas. Mestre e doutor em Filosofia Antiga pela Universidade Estadual de Campinas (UNICAMP). tigosofia@gmail.com 


\section{INTRODUÇÃO}

À "eterna crise" do ensino jurídico (ALVES, 2008, p. 242), têm sido contrapostas, nas últimas décadas, importantes estudos críticos que, com o auxílio de outras áreas do conhecimento, como as Ciências Sociais, a Filosofia e a Pedagogia, denunciam seu caráter dogmático, formalista, abstrato, distanciado da realidade e pretensamente neutro.

Nesse sentido, já em 1986, Relatório do Conselho Nacional de Desenvolvimento Científico e Tecnológico - CNPq criticava o funcionamento das Faculdades de Direito como "meros centros de transmissăo do conhecimento jurídico oficial", ocupados em "reproduzir a sabedoria codificada e conviver respeitosamente com as instituiçóes que aplicam (e interpretam) o direito positivo" (FARIA, 1987, p. 34).

Náo se pode negar avanços nos programas dos cursos jurídicos no país e seu amadurecimento em termos científicos de uma maior capacidade de autoquestionamento. Contudo, se, com a repetiçấo, as críticas se tornam lugar comum, os aspectos criticados ainda prevalecem. A educaçáo jurídica ainda é preponderantemente ensino de uma doutrina que, ideologicamente, constrói-se sobre a afirmaçăo abstrata da justiça, igualdade e outros valores, princípios e direitos, insistentemente negados em sua prática.

No cenário brasileiro, marcado pela inexperiência da democracia e por uma cultura de profundo desrespeito aos direitos humanos, a formaçăo jurídica năo assume a amplitude que lhe caberia constitucionalmente. Como todo processo educacional, essa formaçáo deve ser orientada ao pleno desenvolvimento da pessoa, sua qualificaçăo para o trabalho e seu preparo para o exercício da cidadania. É o que determina o artigo 205 da Constituiçáo Federal.

Em sua amplitude, a educaçăo há de se fazer, necessariamente, por determinaçăo constitucional, como uma educaçăo que, sem descuidar da constituiçăo e crescimento do indivíduo como pessoa, de acordo com seus projetos pessoais, consolide-se como formaçáo para a promoçăo e aprofundamento do Estado Democrático de Direito (RANIERI, 2009, p. 380).

Isso vale, evidentemente, para qualquer nível e área da formaçăo. No âmbito da educaçâo jurídica, todavia, adquire uma significaçăo especial, considerando os papeis a serem assumidos pelos profissionais do Sistema de Justiça na efetivaçăo dos direitos dos cidadáos e as funçóes de destaque que historicamente lhe foram conferidos, nas instâncias do sistema político-governamental, năo raro com exclusividade (juízes, promotores, etc.).

Com efeito, como previsto no Plano Nacional de Educaçáo em Direitos Humanos, a democracia, entendida como regime alicerçado na justiça social e no respeito integral aos direitos humanos, é fundamental para o reconhecimento, a ampliaçấo e a concretizaçăo desses mesmos direitos (COMITÊ NACIONAL DE EDUCAÇĀO EM DIREITOS HUMANOS, 2007, p. 24).A formaçăo do profissional do Sistema de Justiça náo pode perder de vista, jamais, sua responsabilidade com o Estado democrático de direito e, para sua efetivaçăo, de uma cultura de respeito aos direitos humanos. ${ }^{4}$

\footnotetext{
4 Vale anotar o que, como previsto no Plano Nacional de Educaçăo em Direitos Humanos, a democracia, entendida como regime alicerçado na justiça social e no respeito integral aos direitos humanos, é fundamental para o reconhecimento, a ampliaçâo e a concretizaçâo desses mesmos direitos (COMITÊ NACIONAL DE EDUCAÇÃO EM DIREITOS HUMẢNOS, 2007, p. 24).
} 
Nesse contexto, o objetivo do presente artigo é refletir sobre o tema da educaçăo jurídica, no Brasil, concebendo-a como formaçăo para a promoçăo dos direitos humanos. Para tanto, traz, ao campo jurídico, reflexôes que, apesar de bastante desenvolvidas e repisadas no âmbito geral das ciências humanas e sociais aplicadas e da filosofia, ainda năo foram devidamente assimiladas no universo jurídico.

Este artigo, portanto, parte da discussăo sobre o significado geral da educaçáo em direitos humanos (1), destacando, nesta, a ideia de autonomia que năo perde de vista a convivência e a inclusáo do outro (2). Analisa, na sequência, o contexto atual do ensino jurídico no Brasil (3) - destacando, nele, vícios ideológicos presentes na transmissăo "bancária" da doutrina dogmática - o artigo avança, na sequência, para a articulaçăo dos conceitos trabalhados com a educaçăo jurídica, propondo caminhos para sua efetivaçăo como formaçăo para a promoçáo dos direitos humanos (4).

Consolida-se, nessa linha, como práxis social emancipadora, na qual a vivência dos direitos humanos na medida em que apreendidos, no ensino, na pesquisa e na extensâo universitária, permitem a construçăo de uma subjetividade autônoma, inclusiva do outro e democrática. Trata-se de ideias apresentadas pelos autores em debate realizado com os alunos de graduaçăo em Direito da Pontifícia Universidade Católica de Campinas, em evento organizado pelo seu Centro Acadêmico, em outubro de 2016.

\section{EDUCAÇÃO EM DIREITOS HUMANOS}

De início, é importante esclarecer o motivo pelo qual a educaçăo - e, nela, a educaçăo jurídica - deve ser uma forma de promover direitos humanos, ao invés de se prestar simplesmente para a satisfaçáo de desejos pessoais do futuro profissional.

Num raciocínio muito simples, nâo seria de todo absurdo pensar numa educaçáo voltada apenas para a satisfaçăo de desejos pessoais se os indivíduos vivessem isolados em bolhas. A questăo é que năo vivemos em bolhas, por mais que alguns pais e educadores insistam em tentar blindar as subjetividades de seus filhos ou pupilos. Também em um raciocínio muito simples, năo é difícil sustentar que todo indivíduo tem o direito de concretizar seus sonhos e projetos particulares com a profissâo que escolher.

Nessa linha, quando se sustenta que educaçăo em geral deve ter como proposta a promoçấo dos direitos humanos, estamos querendo dizer que o processo formativo deve levar em conta, primeiro, que todos os indivíduos vivem em sociedade e, no caso do Brasil, em uma sociedade muito plural e desigual.

Em segundo lugar, uma formaçâo que busca promover direitos humanos também deve garantir a possibilidade de realizaçăo de projetos individuais ao mesmo tempo em que atribui a cada um a responsabilidade pelos seus projetos, uma vez que conscientiza cada indivíduo que sua existência e sua individualidade somente acontecem em relaçăo ao coletivo que o circunda. Portanto, essa formaçăo năo pode gerar uma atomizaçăo do indivíduo em relaçăo ao coletivo. Em outros termos, ao mesmo tempo em que a educaçăo em direitos humanos tem o propósito de permitir que cada um busque sua felicidade, ela também assume a tarefa de criar condiçôes para que essa busca náo seja um processo egoísta. 
Como fica evidente, uma educaçâo cujo propósito é promover direitos humanos nâo tem como objetivo a anulaçâo dos sonhos pessoais de ninguém. Muito pelo contrário, além de assegurar a realizaçáo desses sonhos e projetos, responsabiliza e situa os indivíduos na realidade concreta que escancara o mundo como um espaço compartilhado por diferentes raças, gêneros, idades, culturas, origens, necessidades, pois educaçâo em e para os direitos humanos significa evidenciar que os direitos humanos sáo destinados a todos e năo apenas a alguns poucos. Daí a necessidade de compreender essa educaçăo nos termos propostos por Maria Victória Benevides:

O que significa dizer que queremos trabalhar com Educaçăo em Direitos Humanos? A Educaçăo em Direitos Humanos é essencialmente a formaçăo de uma cultura de respeito à dignidade humana através da promoçáo e da vivência dos valores da liberdade, da justiça, da igualdade, da solidariedade, da cooperaçăo, da tolerância e da paz. Portanto, a formaçáo desta cultura significa criar, influenciar, compartilhar e consolidar mentalidades, costumes, atitudes, hábitos e comportamentos que decorrem, todos, daqueles valores essenciais citados - os quais devem se transformar em práticas (BENEVIDES, 2001).

Nessa linha, a educaçâo que pretende formar seres humanos para defender e promover direitos fundamentais de todos os seres humanos é um processo que, com a vivência de valores fundamentais, busca emancipar cada sujeito que, pelas razôes mais variadas, acaba sendo levado a acreditar que a vida acontece em volta do próprio umbigo e fazer esse sujeito sair da condiçăo isolada de mero indivíduo e assumir o papel de cidadăo. Eis o motivo pelo qual o artigo 205 da Constituiçăo Federal diz expressamente que a educaçăo busca năo apenas a qualificaçăo para o trabalho, mas também o pleno desenvolvimento da pessoa e seu preparo para o exercício da cidadania.

\section{EDUCAÇÃO, EMANCIPAÇÃO E AUTONOMIA}

Só é possível falar de uma educaçâo que promova a emancipaçâo e a efetivaçăo das potencialidades dos indivíduos em sociedade à medida que esta se dispóe a promover a autonomia daqueles. Ou estamos do lado de um projeto pedagógico que aponta para o horizonte da autonomia dos indivíduos ou enfrentaremos o abismo de uma educaçáo encabrestadora, alienante e estéril. A construçăo de uma educaçăo transformadora e libertária passa, necessariamente, pela noçấo de autonomia e esclarecimento dos indivíduos em sociedade. Essa autonomia e esse esclarecimento só podem ser acessados com a saída do homem da condiçâo de menoridade auto-imposta. Essa menoridade é a incapacidade de servir-se de seu entendimento sem a orientaçăo de um outro (KANT, 2004, p. 11). Mas eis aí um grande problema! Como atingir o esclarecimento e, por consequência, a autonomia em uma sociedade que valoriza uma educaçăo para o adestramento, para a adequaçăo e náo para a liberdade?

Parte de sua teoria da educaçấo, exposta em uma de suas principais obras, A República, Platăo, no Livro III, (PLATẢO, 1996, p.101) torna muito clara a ideia de que todo educador, fazendo referência aos rapsodos responsáveis por contar histórias às crianças, devem ser sempre vigiados, pois seu poder de formaçăo pode deixar traços duradouros na educaçăo das crianças mais do que aqueles que cuidam do corpo. Nâo pudemos deixar de notar o quanto essa análise de Platăo está presente naquilo que pretendemos chamar aqui de "cultura da informaçăo". Essa cultura da informaçăo deve 
ser entendida para além do simples conceito veiculado de que a informaçăo e a educaçăo nos é dada pelas instituiçōes (escola, família, Estado, etc.), mecanismos e meios de comunicaçấo estabelecidos pela sociedade contemporânea. A educaçăo e a informaçâo devem ser entendidas, assim, como toda e qualquer transmissăo de ideias feita pelo ser humano. Desde criança somos treinados a escutar antes mesmo de processar as informaçôes que nos sâo passadas.

O próprio fato de recebermos um nome, para atendermos ao chamado deste, nos indica esse treinamento, que năo acreditamos ser instintivo, para a escuta. Esse treinamento para a escuta é naturalizado e exponenciado pela educaçăo que segue a ideologia da sociedade do consumo. Nesse modelo de sociedade, nada melhor que uma educaçăo para o adestramento e a adequaçáo dos indivíduos para a realizaçăo de tarefas específicas sem jamais se colocar de maneira crítica diante dessa imposiçáo. O treinamento para a escuta na sociedade de consumo é peça fundamental para uma educaçâo alienante e extirpadora do processo de autonomia dos indivíduos.

Nada é mais sintomático nesse modelo de educaçăo que a estrutura de nossas escolas e universidades. Alunos e professores sâo ensinados, desde sempre, quais sáo suas funçóes nos atos de fala e escuta dentro de sala de aula. O processo educacional é limitado e engessado, năo levando em consideraçáo as características de todos os participantes do processo. Por fim, uma educaçăo para a escuta é uma educaçăo alienante, cujo propósito final é a produção de peças capazes de integrarem o sistema sem se contraporem a este. Mas isso é um problema histórico.

Como o próprio Platăo diz, é na infância que encontramos o homem em sua fase mais maleável e suscetível de formaçăo. Portanto, năo se pode negar que desde a mais tenra infância somos treinados a receber informaçóes de todo o tipo. Por outro lado, em momento algum somos treinados, mesmo que superficialmente, para analisar e processar, de modo crítico, todas as informaçōes recebidas. Em inúmeros casos, ao recebermos a informaçâo, transmitida como uma ordem ou uma instruçâo por nossos pais, professores ou responsáveis, náo nos é permitido refletir sobre tal informaçăo, cabendo apenas acatá-la.

Năo se quer com isso sugerir que os filhos se insurjam contra os pais e muito menos dizer que a criança teria plena e total capacidade de discernir o que seria colocar o dedo na tomada, por exemplo, entre outras coisas. 0 que se pretende é ressaltar que esse treinamento para a escuta e recebimento de informaçăo já se inicia na infância, momento de maior maleabilidade na formaçăo de nossa personalidade, e encontra seu ápice já na fase adulta.

As ideias incutidas desse modo na mente de uma criança podem se tornar, na fase adulta, justamente as convicçōes opostas àquelas que supostamente deveria possuir. É assim que todo tipo de crença, superstiçâo, pré-conceitos etc., săo impostos às pessoas, as quais nâo têm outra saída, devido ao treinamento que lhes foi dado desde a infância, a năo ser repetir tais opiniōes na vida adulta. Somente uma educaçăo libertária pode permitir a ruptura com esse processo que é assumido como natural na sociedade contemporânea.

O nosso modelo de ensino reverbera esse discurso e faz a sala de aula entoar o cântico do silêncio. É nesse sentido que podemos falar de uma separaçáo entre o ensino e a humanizaçăo das pessoas. $\mathrm{O}$ ensino destoa dos valores humanísticos à medida que 
tolhe o aluno e faz com que a sala de aula seja local de despejo de informaçôes. Nâo se pensa e nem repensa a informaçâo repassada. Para a lógica do mercado, vale mais um livro bem decorado do que um conceito desconstruído.

Devido esse treinamento para a escuta acrítica das informaçōes, a sociedade contemporânea tende a aceitar com grande facilidade as informaçóes que lhes săo jogadas goela abaixo, seja pelos tutores, pelos meios de comunicaçâo e sua propaganda deturpada, seja pelas ideias de um líder religioso, seja por amigos. Se enquanto crianças somos treinados para sermos uma esponja, enquanto adultos somos a configuraçâo perfeita dessa esponja em atividade. Mas essa facilidade com que se manifesta a aceitaçăo das ideias transmitidas por essa cultura de informaçáo náo é acidental ao indivíduo que a recebe.

Como afirmamos, o treinamento para a escuta acrítica se inicia na infância, é reafirmado e consolidado na adolescência, encontrando no indivíduo já formado sua efetivaçăo completa. Esse fenômeno da aceitaçăo da informaçáo recebida sem o mínimo critério de avaliaçăo está presente inclusive no meio acadêmico. Por um lado, se percebe um comodismo intelectual nos pesquisadores em diversas áreas do mundo acadêmico, os quais preferem se ancorar literalmente nas ideias já consagradas por "grandes autores" e simplesmente se relegam à funçăo de nada mais fazer do que reproduzir aquele pensamento com a desculpa esfarrapada de que estáo propondo uma nova leitura ou uma explicaçáo mais adequada do autor defendido. Por outro lado, as próprias instituiçôes rejeitam de maneira imediata qualquer tipo de manifestaçăo de pensamento livre que se considere crítico e que estabeleça um processo dialógico de tensảo com o status quo.

Com isso, nos deparamos com um incomodante paradoxo: como nos livrar desse estado de esponja consolidado se ao mesmo tempo nos colocamos como essa esponja receptora e acrítica? Se há algum papel para os pedagogos, filósofos e críticos da contemporaneidade, sem eximir dessa funçâo outras áreas, esse papel seria o de promover a libertaçáo desse estado de esponja acrítico e possibilitar, através de uma educaçáo libertária e uma guerra ferrenha contra a cultura de informaçăo de massa, o acesso às próprias capacidades críticas do ser humano, o qual deverá passar desse estado acrítico para um crítico e, portanto, de autonomia.

Em seu texto, Pedagogia da Autonomia, Paulo Freire (FREIRE, 2006) deixa claro que os fundamentos para uma educaçáo libertadora sâo a ética, o respeito à dignidade humana e o estímulo à autonomia.

Um exercício permanente na prática pedagógica deve ser o de uma educaçâo que gere a consciência nos alunos de que eles sấo sujeitos de seu processo educacional. Nesse sentido, eles năo podem ser meramente espectadores a título de restringirem suas potencialidades. Gerar essa consciência é fundamental para se libertar daquele treinamento para escuta que foi naturalizado em nossa sociedade e que visa impedir a autonomia dos indivíduos. Posto desse modo, náo resta dúvidas de que nossa leitura ataca diretamente a estrutura da sociedade contemporânea, baseada, acima de tudo, na mercantilizaçâo das relaçôes, da reificaçăo do outro, no acúmulo e no descarte desenfreado.

Quando falamos de educaçăo em direitos humanos e emancipaçăo, estamos tratando, portanto, de um processo de construçăo de autonomia. Uma autonomia, contudo, que náo significa exclusăo do outro, que năo se dá em detrimento do outro. 
Quem năo experimenta o valor da liberdade, do respeito, do reconhecimento, dificilmente entenderá a importância de promover esses valores no relacionamento com os outros. Quando falamos de emancipaçâo e direitos humanos, estamos tratando de um processo de construçăo de autonomia que nâo desconsidera o fato incontestável que vivemos e compartilhamos um mesmo espaço geográfico e político plural.

Nessa linha, nos parece central a afirmaçăo de Theodor Adorno, quando o teórico frankfurtiano afirma: "A exigência que Auschwitz năo se repita é a primeira de todas para a educaçăo".

A referência à Adorno nâo é sem propósito. Essa afirmaçâo do teórico frankfurtiano busca demonstrar a preocupaçâo com o genocídio dos judeus durante a Segunda Guerra Mundial e, além disso, demonstra a preocupaçăo com a necessidade de pensar a educaçâo após Auschwitz como um processo de sensibilizaçâo dos seres humanos para a compreensâo das diferenças a partir da compreensâo do seu próprio espaço-tempo.

No caso brasileiro, Auschwitz teria uma funçâo pedagógica específica que exigiria uma situaçăo histórica e política definida no contexto nacional. A missâo da educaçâo emancipadora, nessa linha, é exatamente permitir que qualquer reflexăo crítica localizada (Auschwitz no contexto da Segunda Guerra) possa ser compreendida e transportada para outras realidades localizadas e também globais.

Ou seja, quando Adorno propóe uma educaçâo que impeça a repetiçâo de Auschwitz, o que ele quer sugerir é que os processos educativos se comprometam a nâo mais repetir o que teria sido, por analogia, Auschwitz no contexto de educaçáo de cada educando. Em outros termos, evitar, comparativamente, que Auschwitz se repita no Brasil, é evitar, por exemplo, que o genocídio indígena, a escravidăo e a ditadura civil-militar se repitam, e isso exige uma educaçấo que situe o educando dentro do espectro de consequências e causas dessas violências no Brasil, năo deixando nenhuma margem para que ele se acomode na situaçăo confortável de um espectador inconsequente como juiz, promotor, advogado ou, ainda, como professor.

\section{O CENÁRIO ATUAL DO ENSINO JURÍDICO NO BRASIL}

É complexa e de difícil soluçâo a questăo que se coloca de como promover essa educaçấo que faça com que o educando perceba e se responsabilize, na condiçâo de sujeito histórico, contrapondo-se à perpetuaçâo de violências locais e globais que impedem grupos de indivíduos de gozarem as mesmas oportunidades e de ocuparem os mesmos espaços que outros grupos gozam e ocupam.

A aprendizagem dos direitos humanos e a prática da autonomia envolve, necessariamente, vivenciar e praticar seus conteúdos no cotidiano do processo educacional.

A personalidade e, numa dimensăo social, a cultura democrática e de respeito aos direitos humanos náo săo um dado, uma dádiva (DEWEY, 1989, p. 88). Săo hábitos construídos e consolidados em espaços e instituiçôes sociais. Năo nascemos democratas nem promotores dos direitos humanos. Utilizando a ideia de educaçâo ética, em Aristóteles, é a partir de nossas vivências e práticas reiteradas que nos constituímos com hábitos num ou noutro sentido.

Deparamo-nos, assim, com uma enorme dificuldade. 
Olhando para o passado brasileiro, o que extraímos é uma cultura de profundo desrespeito aos direitos humanos. Se a Constituiçăo de 1988 é um marco jurídico fundamental da transiçâo democrática e da institucionalizaçăo dos direitos humanos no país, cumpre observar, por outro lado, que seu texto é arremessado no curso de um processo histórico em que a populaçăo năo o havia internalizado tais concepçôes, nem poderia, como vivência própria.

Enfim, apesar de sua importância, năo significou sua internalizaçăo em hábitos e atitudes. Pois estes năo se promulgam com textos normativos, por mais bem-intencionados que sejam.

Somos inexperientes - para náo dizer analfabetos - nessas coisas de democracia e direitos humanos. E o somos porque nossa história é uma história de autoritarismo, de violência, de náo-diálogo. Eis o ponto de partida, portanto, legado do passado. É o que temos para começar. A aprendizagem da democracia e dos direitos humanos, a capacitaçáo e habituaçâo às práticas democráticas e respeito ao outro, será a partir dessa nossa incipiente experiência (nossa inexperiência, portanto). Isso se aplica à educaçâo jurídica. O cenário é socialmente perverso.

O ensino jurídico se desenvolve, preponderantemente, como transmissăo de uma doutrina jurídica abstrata e pretensamente neutra. É a "educaçăo bancária" tâo criticada por Paulo Freire, em que o ensinar é distorcido, tornando-se "ato de depositar". Em vez de se comunicar, o educador impóe seus comunicados (FREIRE, 2011, p. 80). E assim, como ideologia, despolitiza e dilui conflitos sociais, estimulando, ao mesmo tempo, uma cultura de litígio restrita a um universo jurídico forense, desligado da realidade nacional.

Além dos conceitos e preconceitos formulados e reproduzidos abstratamente por doutrinadores que, em sua maioria, săo ideologicamente orientados para a reproduçâo desses conceitos e para a proteçấo dos interesses dos grupos econômica e politicamente privilegiados, o ensino jurídico ainda está fortemente embasado na cultura do litígio, da disputa que, em última instância, faz valer a lei do mais forte. Essa lei do mais forte, como se sabe, năo é a lei do que trabalha mais ou do que se esforça mais, mas do que pode pagar mais, do que pode influenciar mais.

Ao invés de formar o do Sistema de Justiça para a soluçăo real de litígios com base em referências teóricas, técnicas e empíricas retiradas da vida concreta (e nâo das crenças e preconceitos de doutrinadores que se equilibram eternamente sobre "discursos de autoridade"), o ensino jurídico ainda hoje se contenta com a formaçáo para a soluçâo meramente jurídica (abstrata; do dever ser) dos conflitos sociais.

Citando Vera Regina P. Andrade e Joăo Maurício Adeodato, Vladimir O. da Silveira e Samyra H. Sanches, destacam:

(...) a Dogmática Jurídica abstrai os conflitos sociais da problemática social, econômica e política na qual estâo inseridos e tenta neutralizá-los, tornando-os "abstratos, interpretáveis, definíveis e decidíveis juridicamente.

Desta forma, a decisăo da Dogmática Jurídica náo elimina o conflito; apenas o neutraliza do ponto de vista jurídico. Em outras palavras, ela "apenas trabalha os meios para que a lide (decidida como coisa julgada, por exemplo) perca sua plausibilidade jurídica: o conflito permanece (...) mas năo pode mais ser alegado em termos jurídico-dogmáticos (SILVEIRA e SANCHES, 2013, pp. 500-501) 
Distantes dos conflitos concretos, muitas vezes blindados por mesadas generosas, dispensados da vida cotidiana no transporte público, de uma jornada de trabalho de 8 horas por dia, poupados do contato direto com litígios concretos durante o processo de formaçăo, grande parcela dos estudantes de Direito se afeiçoam e criam um fetiche pelo litígio pautado em discussôes e disputas argumentativas abstratas e absolutamente distantes das necessidades sociais, uma vez que as tristezas, as angústias e os medos que permeiam os litígios săo, para grande parcela desses estudantes, apenas teoria, mera simulaçâo insensível.

A cultura do litígio consolidada sobre conceitos abstratos e quase mirabolantes só faz sentido em contextos em que os indivíduos estăo mais dispostos a se digladiar do que a se entender. Como nossa realidade socioeconômica, racial e política evidencia um cenário de desigualdades, essa cultura da disputa acaba servindo para dar tons de legitimidade às opressōes que na lei sâo proibidas, mas que nos processos marcados, muitas vezes, por corrupçăo, machismo, racismo e também por opressâo simbólica (fóruns e salas de audiências suntuosas, as vestimentas dos profissionais da Justiça, o linguajar etc.), acabam sendo autorizadas, senâo estimuladas.

Como nâo é mais recomendável inscrever no texto da lei de forma tăo escancarada a legitimidade da dominaçâo do mais forte pelo mais fraco, a cultura do litígio é fortalecida como forma de "oprimir nos termos da lei". Nesse sentido, năo têm sido poucas as manifestaçóes de juízes, promotores, desembargadores e outros agentes do sistema de Justiça que aplicam a "lei justa" no sentido de que a criaçăo de foros, procedimentos e julgamentos de exceçăo, à margem da legalidade e sem qualquer preocupaçâo com a soluçâo estrutural dos problemas, nâo é tăo ruim como pode parecer para alguns de nós.

Num tempo em que a arte de fazer o direito se vê esgotada no bisturi asséptico do fazer instrumental a partir de normas que a tecnologia conforma aos interesses de mercado, a própria ciência do direito se torna instrumentaçâo para a açấo e, com isso, perde o seu sentido, especialmente em se converter em instrumental para processos de dominaçăo, e se separa vez e vez mais da funçáo que a enobrece, a de salvaguarda da dignidade humana e da luta contra o desenfreado confronto frente ao princípio da realidade (BITTAR, 2011).

O ponto central é que desde a implantaçăo dos dois primeiros cursos de Direito no país, Olinda e Sáo Paulo, esse espaço acadêmico tradicionalmente foi reservado às elites econômicas, àqueles que Lilia Moritz Schwarcz chamou "os eleitos da naçăo" em sua obra $O$ espetáculo das raças. Além de um espaço reservado às elites, a proposta dos cursos de Direito se desenvolveu com base em uma cultura bacharelista: "O prestígio advinha, no entanto, menos do curso em si, ou da profissăo stricto sensu, e mais das cargas simbólicas e das possibilidades políticas que se apresentavam ao profissional de direito" (SCHWARCZ, 1993, p. 142).

O elitismo econômico (que năo se confunde com o intelectual) e o prestígio baseado em privilégios travestidos de oportunidades acabaram consolidando uma cultura que vê no curso de Direito mais uma oportunidade de ascensâo ou manutençăo de status econômico do que uma oportunidade de formaçăo para a promoçâo da justiça social de que, ainda hoje, o país é tăo carente. Nâo é demais afirmar que essa cultura se perpetua até hoje, uma vez que é bastante indagar aos estudantes de um curso de Direito o que ele quer fazer da vida para verificar que as possibilidades estăo limitadas à advocacia, promotoria ou magistratura. 
Essa limitaçâo demonstra nâo apenas uma ausência de compreensăo do que é o próprio Direito, mas também evidencia que atualmente as possibilidades dadas pelos professores (principais responsáveis pelas escolhas profissionais dos estudantes) é ainda mais restrita do que no século XIX, quando grande parte dos bacharéis seguiam carreiras políticas. Raros sâo os educadores que apresentam aos estudantes do curso de Direito possibilidades de atuaçâo profissional em assessorias legislativas, assessorias em cargos no Executivo ou em organismos internacionais.

A própria carreira docente é vista como atividade secundária nos cursos de Direito, năo sendo raro estudantes indagarem aos professores se eles "apenas dăo aula". Os cursos de Direito, em razăo da primazia simbólica atribuída ao bacharel, apenas recentemente começaram a se preocupar com a pesquisa científica. O Direito sempre foi resultado de positivaçăo, interpretaçăo e imposiçăo de discursos de autoridade pouco preocupados com a realidade plural do país. A. M. Hespanha diz o seguinte sobre o Direito ocidental:

(...) Ele está pensado por brancos (homens brancos, diria a jurisprudência feminista), fundado na sua cultura (na sua visáo do mundo, na sua racionalidade, na sua sensibilidade, nos seus ritmos de trabalho, nos seus mapas do espaço, nos seus conceitos de ordem, de belo, de apropriado etc.) e prosseguindo, portanto, os seus interesses. Conceitos jurídicos formados na tradiçăo jurídica ocidental (como propriedade, trabalho, família, roubo, pudor e, até, escravidăo) foram exportados como se fossem categorias universais e aplicadas a povos a que eles eram completamente estranhos, desagregando as suas instituiçóes e modos de vida e aplicando-lhes os modelos do convívio jurídico e político do ocidente (HESPANHA, 2009, p. 295).

\section{EDUCAÇÃO JURÍDICA PARA PROMOÇÃO DE DIREITOS HUMANOS: PERSPECTIVAS E POSSIBILIDADES}

Renovam-se perguntas. Como reverter esse processo? Como ampliar os sentidos possíveis da educaçăo jurídica, à luz do texto constitucional, num contexto em que a organizaçăo escolar, os professores e os alunos reproduzem estruturas e conceitos avessos à cultura de direitos humanos?

Năo podemos nos livrar, tăo facilmente dos velhos hábitos de pensar e nunca podemos nos livrar deles de uma só vez. Afinal, para desenvolver novas ideias, somos compelidos a usar algo das antigas como instrumento de compreensâo e comunicaçâo (DEWEY, 2004, p. 43). É o que dispomos.

Năo é a pretensâo, aqui, evidentemente, trazer respostas prontas a todos os complexos problemas levantados. Trazemos, apenas, alguns pontos de reflexâo, possibilidades de caminho a serem trilhados. Tudo para tentar romper a repetiçăo do cenário perverso que se busca superar, iniciando um movimento em favor de uma educaçăo jurídica efetivamente orientada à promoçáo dos direitos humanos.

\section{i) Educaçăo jurídica: direito como práxis social emancipadora}

Como visto, o ensino jurídico, em seu estágio atual, limita-se, no mais das vezes, a uma teoria sem prática, ao ensino como transmissâo unilateral de conceitos que nâo preparam nem habituam o estudante à sua efetivaçăo prática, como um compromisso 
social e político do profissional. Săo doutrinas prontas, esvaziadas de direitos humanos e democracia, no conteúdo e na forma como transmitidos. Quanto à prática profissional, componente curricular obrigatório, resume-se e se deturpa em prática forense na cultura do litígio.

Pratica-se, assim, uma "formaçăo acadêmica que distancia cada vez mais o profissional do Sistema de Justiça de sua responsabilidade como sujeito de transformaçáo social e da visăo humanista tăo necessária na atualidade" (ALVES, 2008, p. 244). Na formaçăo acadêmica do jurista, "direitos humanos" săo, nâo raro, reduzidos a significantes totalmente esvaziados de conteúdo. Conceitos sem nenhuma correspondência na experiência cotidiana.

\section{ii) Faculdade de direito como espaço de respeito aos direitos humanos}

Nesse sentido, uma educaçăo jurídica para a promoçăo de direitos humanos passa, necessariamente, por todas as instâncias da convivência acadêmica. Abrange, portanto, as atividades de ensino, pesquisa e extensáo, os métodos de aprendizagem, a transversalidade dos conteúdos programáticos, a organizaçăo curricular e, também, a administraçáo da instituiçăo de ensino.

Năo basta a atuaçăo isolada de um ou dois professores progressistas, todo o tempo desditos e facilmente engolidos pela estrutura conservadora e pelo descompromisso de profissionais que, encapsulados em egoísmo, ministram aulas como bico e sem nenhuma preocupaçăo com os reflexos que sua prática pedagógica terá na realidade social circundante.

Em relaçăo à administraçăo das faculdades e instituiçóes, importa destacar que o princípio constitucional da "gestăo democrática do ensino público", afirmado pelo artigo 206, inciso VI, da Constituiçăo Federal, faz a referência expressa ao espaço "público" e insere-se, ao mesmo tempo, no âmbito de um sistema constitucional que nos constitui como Estado democrático de direito, amparado em consistente conjunto de direitos fundamentais. O princípio, assim, nâo deve ser lido mais como limitador da democracia e da cultura de direitos humanos que lhe é inerente nos estabelecimentos educacionais em geral, pública ou privada. Năo é demais acrescentar, ademais, mesmo quando prestado pela iniciativa privada, a atividade educacional nâo perde seu caráter eminentemente público.

Observa-se, ainda, que pautas novas têm se apresentado inclusive aos movimentos estudantis nas faculdades de Direito, como a inclusăo de disciplinas práticas e teóricas sobre direitos humanos e o fortalecimento da pesquisa, através de iniciaçâo científica e pós-graduaçâo stricto sensu, e da extensấo. Atividades teóricas conjugadas com práticas de direitos humanos na formaçáo dos profissionais do Sistema de Justiça náo apenas contribui para a formaçâo humanística que promove o valor da cidadania, mas também acaba funcionando como uma forma de promover a transversalidade desses temas em outras disciplinas, uma vez que o estudante que compreende a complexidade social, política e histórica do Direito inevitavelmente demanda dos professores de outras disciplinas reflexôes e respostas que considerem essa complexidade.

A prática dos conteúdos ministrados, dessa forma, permite ao estudante de direito apreendê-lo com significados que se verificam, que apresentam correspondência em seu cotidiano escolar. 


\section{iii) Educaçăo jurídica como diálogo e conflito}

A prática dos direitos humanos remete à ideia de diálogo. Nâo um diálogo dócil, mas profundamente conflituoso. Na obra A ciência jurídica e seus dois maridos, Luís Alberto Warat dá definiçấo à democracia que se estende, com perfeiçăo, à educaçăo jurídica: um espaço de diálogo e de conflito de ideias, marcado pela "procura de conflitos. O importante nela é assegurar a procura, năo a soluçăo" (WARAT, 2000, p. 34).

É um conflito, portanto, que nada tem a ver com a discriminatória, abstrata e infecunda cultura forense do litígio. E é, concomitantemente, um conflito que pode nos afastar da violência, tâo praticada hoje pelos atores do direito (professores, juízes, promotores, etc.).

O ambiente dialógico do conflito é o ambiente da pluralidade, da contradiçăo, da dialética de crítica e fundamentaçâo de pontos de vista, e, por tudo isso, o ambiente fundamental da aprendizagem (HABERMAS, 2012, p. 57). É o ambiente da revisâo e ampliaçăo do conhecimento; do crescimento e abertura ao mundo e ao diferente, mediante a "participaçăo no outro" (MEAD, 1992, p. 253). Remete, ainda com Warat, ao "estado de permanente nascimento" (WARAT, 2000, p. 34).

Mediante a inclusăo e reconhecimento do outro, a possibilidade de questionamento e superaçăo de dogmas jurídicos, a educaçăo jurídica dialógica pratica os direitos humanos ensinados. Forma e conteúdo se fundem.

\section{iv) Educaçăo jurídica como prática de pesquisa e extensăo}

Trata-se, assim, de inversăo radical no modelo que se repete, com a aula expositiva, no qual é atribuído ao docente o papel de trazer a soluçáo dos problemas (problemas que nem sequer o aluno pode colocar), num conhecimento pronto e acabado.

Estimular o conflito, a procura, implica que a educaçăo jurídica deixa de se restringir ao aspecto do ensino, como transmissấo de conhecimento, e passa a destacar os outros aspectos da educaçấo superior, a saber: a pesquisa e a extensâo.

Por pesquisa, entende-se a investigaçáo científica compartilhada, meio de produçăo, revisăo, aprofundamento do conhecimento. Quanto à extensâo, é a difusâo do conhecimento. Nos termos da Lei de Diretrizes e Bases (Lei no 9.394/1996), "a difusâo das conquistas e benefícios resultantes da criaçấo cultural e da pesquisa científica e tecnológica geradas na instituiçấo" (Art. 43), por meio de serviços especializados (assessoria jurídica popular e assistência judiciária, por exemplo).

Discutir e aplicar propostas pedagógicas que aproximem o estudante de Direito de casos concretos de pessoas concretas, superando as abstraçóes dos exemplos reproduzidos em muitas salas de aula envolvendo Tício e Mévio, é fundamental para a formaçăo de profissionais aptos para atuarem na promoçăo de direitos humanos. A respeito da importância do trabalho de campo nos cursos de Direito, Roberto Kant de Lima e Bárbara Batista afirmam:

Entretanto, é preciso de início esclarecer que a pesquisa empírica é um desafio significativo para o campo do Direito, seja porque os seus operadores náo estăo socializados com essa metodologia, seja porque estăo acostumados a pensar o Direito a partir de ideais abstrato-normativos (dever-ser) que costumam obscurecer a visăo do campo para práticas e rituais que os contrariam, que se tornam objeto 
de estigma e, no limite, de denúncia, acusaçăo e criminalizaçăo, năo de pesquisa. Além do fato de que, socializados na lógica do contraditório, da disputatio, seja no processo, seja na produçâo da dogmática, os juristas săo muito pouco afeitos à lógica da argumentaçấo, voltada para consensualizaçôes provisórias e sucessivas (KANT DE LIMA e BATISTA, 2014).

A pesquisa tem se mostrado o espaço de reflexáo crítica sobre o Direito e as desigualdades sociais, uma vez que, diferente dos manuais, é sempre resultado de um trabalho submetido à crítica dos pares. Nesse sentido, do mesmo modo que a inserçăo das disciplinas de direitos humanos nos primeiros anos do curso, a complementaçăo das doutrinas presentes nos manuais com artigos científicos desenvolvidos por juristas pesquisadores tem contribuído para aquela compreensáo que nos referimos acima, qual seja a compreensăo de que o Direito tanto pode ser um instrumento de garantia de igualdade de oportunidades e de participaçáo a todos, como pode ser apenas um instrumento de perpetuaçăo de ideias egoístas travestidas em doutrina e também de legitimaçấo de injustiças sociais.

No que se refere à extensáo, a crítica ao isolamento da Faculdade de Direito da realidade social e os sempre retomados apelos abstratos à "inserçâo da universidade na comunidade" (SOUZA SANTOS, 2010, p. 206) năo podem se perder em atividades práticas restritas aos fóruns e estágios em escritórios de advocacia.

O sentido da intervençáo extensionista da Faculdade de Direito vincula-se à atuaçáo na soluçáo dos problemas sociais, pela via do direito e da garantia dos direitos humanos. Isso por meio náo apenas da assistência judiciária, mas também e principalmente pela atividade de mediaçấo e conciliaçấo e por trabalhos de assessoria jurídica popular junto a movimentos sociais.

\section{v) Respeito à legalidade democrática: cidadania de "cima baixo para cima"}

Educar em e para os direitos humanos na formaçáo dos profissionais do Sistema de justiça significa, portanto, conciliar a necessidade de compreensâo do valor da legalidade democrática como garantia de segurança nas relaçóes sociais com a necessidade de compreensăo de que pelo fato de a sociedade ser o resultado de um processo histórico marcado por permanentes mudanças, a legalidade poderá e deverá corresponder a essas mudanças assegurando năo uma permanência estática dos acordos sociais positivados, mas fundamentalmente a justiça social nos processos históricos de repactuaçấo.

Afirmar que a legalidade deve corresponder a essas mudanças, nesse sentido, năo significa que a legalidade poderá ser precarizada ou abandonada durante esses processos de repactuaçáo dos acordos sociais. Pelo contrário, será a própria legalidade o meio e também o fim desse processo de negociaçăo, argumentaçăo e repactuaçăo que, numa democracia, deve ser resultado daquilo que Evelina Dagnino denominou "cidadania de baixo pra cima". Ensinar o valor da cidadania de baixo para cima é a grande missâo do ensino jurídico que estamos propondo aqui.

Nesse sentido, năo é demais lembrar que o conceito de educaçăo apresentado no artigo $1^{\circ}$ da Lei de Diretrizes e Bases da Educaçăo Nacional consolida um conceito de educaçăo que náo se resume ao processo que ocorre nas instituiçóes de ensino e pesquisa, ou seja: "A educaçăo abrange os processos formativos que se desenvolvem 
na vida familiar, na convivência humana, no trabalho, nas instituiçóes de ensino e pesquisa, nos movimentos sociais e organizaçōes da sociedade civil e nas manifestaçóes culturais".

O Plano Nacional de Educaçăo em Direitos Humanos, por sua vez, diz que o princípio básico norteador da educaçăo em direitos humanos como prática permanente, contínua e global, deve estar voltado para a transformaçấo da sociedade, com vistas à difusâo de valores democráticos e republicanos, ao fortalecimento da esfera pública e à construçâo de projetos coletivos.

\section{CONSIDERAÇÕES FINAIS}

Dessa forma compreendida, a educaçăo jurídica ao mesmo tempo em que pode promover a aprendizagem e a convivência dos direitos humanos, efetiva-se como fonte de reconstruçăo desses direitos. Isso, na aproximaçăo da teoria jurídica a práxis da qual emerge e na qual é aplicado, no autoquestionamento científico de seus pressupostos, na prática do diálogo, da investigaçăo científica e da extensâo universitária.

Fonte de direito, na forma como se conduz, capacitando e habituando os atores do direito a uma cultura dos direitos humanos, a partir de seu exercício. Fonte de direito também, no conteúdo produzido, permanentemente questionado, revisto, reconstruído, melhorado - tornando mais plenos os projetos de sentido trazidos na Constituiçáo Federal - compartilhado e democratizado.

Possibilita-se, assim, que a educaçăo jurídica para a promoçăo de direitos humanos, na atualizaçăo dos objetos educacionais constitucionais, promova, efetivamente, a ideia de autonomia, socialmente compreendida.

É a autonomia que náo exclui o outro, que năo se realiza na ideia de sucesso pessoal egoísta, em detrimento dos demais e indiferente aos graves problemas sociais a serem enfrentados pelo direito.

É autonomia, enfim, que supóe o outro, o diferente, o inclui, numa cultura de profundo respeito aos direitos humanos, permanentemente reconstruídos e incorporados à personalidade emancipada. 


\section{REFERÊNCIAS}

ADORNO, T. W. Educaçăo e Emancipaçăo. Trad. Wolfgang Leo Maar. 4. ed. Rio de Janeiro: Paz e Terra, 1995

ALVES, E. Ensino jurídico como fonte de direito. In CARLINI, Angélica e outros. 180 anos de ensino jurídico no Brasil. Săo Paulo: Milennium, 2008.

BITTAR, E. C. B. Ética, técnica e direitos humanos. In. Revista Brasileira de Estudos Políticos. Belo Horizonte, n. 103, p. 139-182, Julho/Dezembro de 2011

. 0 direito na pós-modernidade (e reflexóes frankfurtianas). 2. ed. rev. atual. e amp. Rio de Janeiro: Forense, 2009.

BENEVIDES, M. V. Educaçăo em Direitos Humanos: de que se trata? In: Convenit Internacional. Săo Paulo: USP. v. 6, pp. 43-50, 2001.

Disponível em: http://portal.mec.gov.br/seb/arquivos/pdf/Etica/9_benevides.pdf. Acesso em 27 de julho de 2015

DAGNINO, E. Os movimentos sociais e a emergência de uma nova noçăo de cidadania. In: Anos 90 - Política e sociedade no Brasil, Evelina Dagnino (org.), Ed. Brasiliense, 1994. p. 103-115.

DEWEY, J. Freedom and culture. N. York: Prometheus Books, 1989.

Reconstruction in philosophy. Mineola/New York: Dover Publication, 2004.

FARIA, J.E. A reforma do ensino jurídico. Porto Alegre: Sérgio Antonio Fabris Editor, 1987.

FREIRE, P. Pedagogia da autonomia: saberes necessários à prática educativa. Săo Paulo: Paz e Terra, 2006

Pedagogia do oprimido. 50. Ed. Rio de Janeiro: Paz e terra, 2011.

HABERMAS, J. Teoria do agir comunicativo. Racionalidade da açâo e racionalizaçâo social. Trad. Paulo Astor Soethe. Săo Paulo: Martins Fontes, 2012.

HESPANHA, A. M. O caleidoscópio do direito: o direito e a justiça nos dias e no mundo de hoje. $2^{\text {a }}$ ed. Coimbra: Almedina, 2009.

KANT, E. Resposta à pergunta: que é iluminismo? In: A paz perpétua e outros opúsculos. Lisboa: Ediçōes 70, 2004.

KANT DE LIMA, R.; BAPTISTA, B. G. L. Como a Antropologia pode contribuir para a pesquisa jurídica? Um desafio metodológico. 2014, 9-37.

MEAD, G.H. Mind, self and society: from the standpoint of a social behaviorist. Edited and with an introduction by Charles W. Morris. Chicago/London: The University of Chicago Press, 1992.

PLATÂO. A República. Trad. Maria Helena da R. Pereira. Lisboa: Fundaçâo Calouste Goubenkian: Lisboa, 1996.

RANIERI, N. B. S. 0 estado democrático de direito e o sentido da exigência de preparo para o exercício da cidadania, pela via da educaçăo. Tese (Livre-docência) - Faculdade de Direito - Universidade de São Paulo. Săo Paulo, 2009. 
SCHWARKCZ, L. M. O Espetáculo das Raças. Sáo Paulo: Companhia das Letras, 1993.

SILVEIRA, V. O.; e SANCHES, S.H.F.N. A reproduçăo do paradigma dogmático da ciência do direito no ensino jurídico e a necessidade de mudanças na pesquisa jurídica, que permitam uma efetiva educaçáo jurídica. In SILVEIRA, V.O; SANCHES, S.H.F.N.; E couto, M. B. Educaçăo jurídica. Săo Paulo: Saraiva, 2013.

SOUSA SANTOS, B. Pela măo de Alice: o social e o político na pós-modernidade. $13^{a}$ ed. Sâo Paulo: Cortez, 2013.

WARAT, L.A. A ciência jurídica e seus dois maridos. 2. Ed. Santa Cruz do Sul: EDUNISC, 2000. 